\title{
Comparative leaf and wood anatomical characteristics of Chrysophyllum (Sapotaceae) relate to taxonomy of the species in Thailand
}

\author{
SAMOESAK PRASAWANG, ANITTHAN SRINUAL ${ }^{\vee}$ \\ Department of Biology, Faculty of Science, Srinakharinwirot University. 114 Sukhumvit 23, Bangkok 10110, Thailand. Tel./fax.: +66-2-649-5000 ext \\ 18101, `email: a.srinual.swu@gmail.com
}

Manuscript received: 26 February 2020. Revision accepted: 22 March 2020.

\begin{abstract}
Prasawang S, Srinual A. 2020. Comparative leaf and wood anatomical characteristics of Chrysophyllum (Sapotaceae) relate to taxonomy of the species in Thailand. Biodiversitas 21: 1578-1587. Anatomical attributes are important tools for taxonomic studies of plants. The present study compared anatomical characteristics (i.e. lamina, petiole and wood) of two species of Chrysophyllum (namely Chrysophyllum cainito L. and C. roxburghii G.Don) belonging to family Sapotaceae in Thailand to develop taxonomic identification keys for two species of Chrysophyllum. Peeling and clearing methods were used for epidermal study, paraffin method for lamina and petiole transverse sections and standard microtome sectioning for anatomical analyses of wood. The findings of this study demonstrated the leaf and wood anatomical features presenting in $C$. cainito differs from those in the species of $C$. roxburghii including 1) shape and outline of epidermal cell wall 2) presence or absence of T-shaped trichome 3) presence or absence of inclusions 4) shape of vascular bundle and accessory bundle in midrib 5) shape of petiole and vascular bundle 6) grouping type of vessel 7) type of axial parenchyma 8) presence or absence of inclusions in rays and 9) thickness of fiber wall. Therefore, these characteristics can be used valuably as additional data in case of taxonomic studies of Thai Chrysophyllum.
\end{abstract}

Keywords: Anatomy, Chrysophyllum, Sapotaceae, Thailand

\section{INTRODUCTION}

The taxonomy of family Sapotaceae at the level of tribe, genus and species has been investigated for several decades. Pennington (1991) concluded that the Sapotaceae is composed of 5 tribes (Mimusopeae, Isonandreae, Sideroxyleae, Chrysophylleae and Omphalocarpeae) approximately 800 species in 53 genera. However, a number of Sapotaceae has been rising consistently due to new discoveries in the Pacific region as well as in the Neotropics (Swenson and Munzinger 2016). For instance, the new species of Chrysophyllum pubipetalum Sossai \& Alves-Araújo and Pichonia munzingeri Gâteblé \& Swenson have been found recently (Sossai et al. 2017; Gâteblé and Swenson 2019). In Thailand, Sapotaceae is represented by 48 species belonging to 10 genera and 3 tribes (Chayamarit 2014; Pooma and Suddee 2014).

The genus Chrysophyllum L. belongs to the tribe Chrysophylleae and it is considered as the second largest genus of Sapotaceae with 71 species (Pennington 1990). The generic name of Chrysophyllum is derived from the Greek word Chrysos meaning 'gold' and Phyllos meaning 'leaf'. The genus comprises 60-70 species which is native to tropical and subtropical regions, especially in America, West Africa and Australia (Shailajan and Gurjar 2014). In Thailand, there are two species of this genus recorded throughout the country, including $C$. cainito $\mathrm{L}$. and $C$. roxburghii G.Don. (Chayamarit 2014; Gardner et al. 2018). The characters of this genus are distinguished by morphological features with pubescent branchlets, arrangement of leaves (i.e. alternate and distichous), lamina is chartaceous to subcoriaceous, elliptic obovate or lanceolate, apex and base are obtusely acuminate and broadly cuneate respectively. The reproductive organs of Chrysophyllum are existing of bisexual flowers and fascicled either in axils of leaves or leaf scars. Calyx consists of a single whorl of five quincuncial sepals, while corolla is campanulate with five lobes. Five stamens insert in corolla tube with hairy or glabrous extrorse anthers, staminodes are absent though. Ovary contains nine to eleven locules and fruits of large berry containing five large flattened seeds or sometimes fewer by abortion. These Thai Chrysophyllum species are distinguished from other genera in the family Sapotaceae by the presence of uniseriate calyx with five sepals and the absence of staminode (Chayamarit 2014; Inyama et al. 2015; Santamaria-Aguilar et al. 2016; Sossai et al. 2017).

Currently, Chrysophyllum species are known to have a large number of benefits, such for producing huge succulent fruits along with ornamental benefits (Parker et al. 2010). In addition, the genus has number of medicinal values, for instance, its ripe fruits are used in curing inflammation of larynx and lung and also consumed as a treatment for diabetes mellitus. The bark of some species is recognized as a roborant medicine and its decoction is used as an antitussive drug (Das et al. 2010). Koffi et al. (2009) claimed that alkaloids, flavonoids, phenols, sterols and triterpenes had been chemically examined in leaf of $C$. cainito, this has been applied to resist diabetes and rheumatoid arthritis. Nonetheless, a number of research 
reveal that leaf extracts of many Chysophyllum species have been used in the application of anticancer, antioxidant, antimicrobial and so on (Mallikarjun et al. 2011; Meira et al. 2014; Li et al. 2015; Mao et al. 2015; Hegde et al. 2016; Ningsih et al. 2016; Doan et al. 2018; George et al. 2018)

In spite of a great number of benefits of the genus to the society, identification of Chrysophyllum has been found to be untenable. Most identification keys were constructed from their leaf and floral features (Chayamarit 2014) which are difficult for the users in identifying the plant because of the non-availability of the flowering stage and morphological similarities of a variety of species. Although, previously, the vital phylogenetic relationships and floral meristic changes data of Chrysophyllum and other genera in Sapotaceae have been already provided (Petersen et al. 2012; Swenson et al. 2013; Faria et al. 2017; Swenson et al. 2018; Borg et al. 2019), other informative aspects, such as anatomy, phytochemistry, ecology and palynology, have been compulsory to distinguish Chrysophyllum. However, anatomical characteristics have been greatly relevant for systematic and ecological information at the subfamily, tribe, genus and species levels in plant taxonomy (Metcalfe and Chalk 1957; Araújo et al. 2010; Almeida-Jr 2013) without flowers and fruits, including detentions of the genus Chrysophyllum due to the regular features appearing in each species.

Metcalfe and Chalk (1957) described leaf anatomical characters of the genus Chrysophyllum in term of the presence of two-armed trichomes, laticiferous element, epidermal cells with straight or sinuous anticlinal walls of varying thickness, stomata normally confined in abaxial surface, mesophyll containing one or more rows of palisade cells and spongy tissue with plentiful intercellular spaces, major vascular strand in the pattern of a closed ring with a flat vascular bundle on adaxial side, laticiferous elements always accompanying vascular bundles and solitary or/and clustered crystals.

Due to close morphological resemblance of three species of Chrysophyllum namely C. cainito, C. albidum and $C$. subnudum some researchers had placed $C$. subnudum as a variety of $C$. albidum. Inyama et al. (2016) pointed out that folia and petiole anatomical characteristics, such as shape of epidermal cell, the number of palisade layers, the number of spongy layers, petiole shape and the number of vascular bundles, were provided to indicate taxonomic reasons for the three taxa to exist $C$. subnudum as distinct species. However, the anatomy of all Chrysophyllum in Thailand has not been reported yet, accordingly, the purposes of this study were to describe the lamina, petiole and wood anatomy of two species belonging to the genus of Chrysophyllum occurred in Thailand and to construct anatomical keys for species identification for the benefit of plant taxonomy.

\section{MATERIALS AND METHODS}

\section{Specimen collection and identification}

Two species of Chrysophyllum including C. cainito and C. roxburghii were examined in this study. The sampling with ten replicates of lamina, petiole and wood of each species was collected from different sites in Thailand in January 2019. Mature leaves were randomly sampled from sun-exposed branches from a number of typical and healthy individuals. The flesh leaf materials were fixed in $70 \%$ ethanol for anatomical studies. In addition, the samples were made as herbarium specimens and deposited at Department of Biology, Faculty of Science, Srinakharinwirot University. Details of samples investigated, vouchers and localities are shown in the Table 1. The specimen identifications were provided in Flora of Thailand Vol. 11 part 4 (Chayamarit 2014) and confirmed by Mr. Sukid Rueangruea a professional academic at Forest Botany Division, Forest and Plant Conservation Research Office, Department of National Parks, Wildlife and Plant Conservation, Bangkok, Thailand.

\section{Anatomical studies}

Peeling and clearing methods

The leaf apex and base were cut out, and then the regions of midrib, leaf margin and the area between midrib and leaf margin were peeled to remove the unwanted epidermis and mesophyll out using a razor blade and cleared in $10 \%(\mathrm{w} / \mathrm{v}) \mathrm{NaOH}$. The pieces of Chrysophyllum sample were stained with $1 \%(\mathrm{w} / \mathrm{v})$ safranin $\mathrm{O}$ and dehydrated with series of ethanol $(50 \%, 70 \%$ and $95 \%)$ for at least 10 minutes in each grade. The specimens were immersed in the mixed solution of xylene and absolute alcohol with a ratio of 1:1 (v/v) and pure xylene for 3-5 minutes in each solution. The epidermal peels were mounted with DePeX mounting medium. The replications of ten leaves were taken in each leaf.

\section{Paraffin technique}

The middle portions of petiole and mature leaf blades which were leaf margin, midrib and the region between leaf margin and midrib were dehydrated in series of TBA (tertiary butyl alcohol). The specimens were infiltrated by paraffin liquid and pure paraffin before embedded into molds. A thin section of $12-14 \mu \mathrm{m}$ was made using a sliding microtome and stained with safranin $\mathrm{O}$ and fast green, ahead of mounting with DePeX mounting medium (Ravichandra 2010). The replications of ten leaves were also conducted in each leaf area of paraffin technique.

Table 1. The species and number of individuals of the Chrysophyllum from Thailand

\begin{tabular}{lllll}
\hline Species & Locality & Coordinates & Habitat & Additional material \\
\hline C. cainito & Muang, Krabi & $8^{0} 05^{\prime} 53^{\prime \prime} \mathrm{N}, 98^{0} 54^{\prime} 36^{\prime \prime} \mathrm{E}$ & Roadside, evergreen forest & S. Prasawang 001/2562 \\
C. roxburghii & Khao Chong, Trang & $7^{0} 32^{\prime} 47^{\prime \prime} \mathrm{N}, 99^{0} 47^{\prime} 32^{\prime \prime} \mathrm{E}$ & Evergreen forest & S. Prasawang 002/2562 \\
\hline
\end{tabular}




\section{Wood sectioning}

Preparation of sections for light microscopy was made by maintaining of stem from adult trees at 1.5-meter height. Then, the wood was cut and trimmed as a cubic in $1 \times 1 \times 1$ $\mathrm{cm}^{3}$. Wood sectioning of 10-14 $\mu \mathrm{m}$ was prepared using a sliding microtome in three surfaces including transverse, tangential and radial sections. The tissues were stained with safranin $\mathrm{O}$ and dehydrated in series of alcohol before mounting with DePeX mounting medium. For terminology and determinations of the quantitative and qualitative features of the wood, the IAWA Hardwood List followed Wheeler et al. (1989). Minimum of 50 measurements for diameter on ten samples of each species were performed.

Eventually, the permanent slides were analyzed and photographed using a LEICA MC170HD microscope. The mensuration of vessel was diagnosed by ImageJ program.

\section{RESULTS AND DISCUSSION}

\section{Anatomical characteristics of Chrysophyllum cainito L. Lamina surface}

The cutin sculpturing was smooth on adaxial surface and striated on abaxial surface. Epidermal cell shape was rectangular with straight wall on adaxial side (Figure 1.A) and irregular with straight or curved on abaxial side (Figure 1.C). Stomata were absent on adaxial side, whereas, paracytic stomata were present on abaxial side (Figure 1.C). Inclusions occurred in epidermal cells. T-shaped trichomes were present solely on abaxial epidermal surface (Figure 1.E).

\section{Lamina and petiole in transverse section}

The outline of leaf margin was acute at tip and slightly downward (Figure 2.E). The region between leaf margin and midrib presented $\mathrm{T}$-shaped trichomes which were attached on abaxial surface. The adaxial cubic epidermal cells were normally observed in this species. Hypodermis or multiple epidermis was absent. The leaves demonstrated bifacial type with 1-3 layer (s) of palisade mesophyll and 10 layers of spongy mesophyll which typical stomata were attached on abaxial surface. Dark red inclusions accumulated in epidermal cells were commonly present (Figure 2.C). Shape of midrib was concave on adaxial surface and convex on abaxial surface with heart shaped vascular bundle and two accessory bundles (Figure 2.G). The outline of petiole in transverse section was concave on adaxial side and convex on abaxial side. Surface of petiole presented T-shaped trichomes. Vascular bundle in petiole was heart shaped without accompanying of accessory bundle. Prismatic crystals generally located in parenchyma tissue in cortex and pith. Laticiferous cells were thoroughly distributing of cortex and pith and intensively surrounding vascular bundle along with gelatinous fibers (Figure 2.A).

Wood anatomical characteristics: Growth ring boundaries illustrated indistinct (faint). Vessels presented in diffuse porous pattern, partly solitary, radial multiple of 2-4 cells and small cluster with diagonal and radial arrangements (Figure 3.A) and average diameter of 63.62 $\mu \mathrm{m}$. Both alternate intervessel pitting (Figure 3.E) and simple perforation plates displayed at each studied vessel. Axial parenchyma was obviously diffused-in-aggregates. Ray width included 1-3 cells (Figure 3.E) with procumbent, square and upright cells mixed throughout the rays without red inclusions (Figure 3.G). The septate fibers observed from transverse section were accompanied by very thick walls (Figure 3.C).

\section{Anatomical characteristics of Chrysophyllum roxburghii G.Don. \\ Lamina surface}

The cutin sculpturing was smooth on adaxial surface and striated on abaxial surface. Epidermal cell shape was jigsaw with sinuous wall on both sides (Figure 1.B and 1.D). Stomata were absent on adaxial side whereas commonly paracytic, rarely anisocytic and cyclocytic stomata (Figure 1.F) were present on abaxial side. Inclusions were absent in epidermal cells. Trichomes were absent on both epidermal surfaces.

\section{Lamina and petiole in transverse section}

The outline of leaf margin was obtuse at tip and slightly downward (Figure 2.F). The region between leaf margin and midrib indicated the absence of trichome on both surfaces. The adaxial rectangular and circular epidermal cells were normally observed in this species. Hypodermis or multiple epidermis was absent. The leaves demonstrated bifacial type with 1 layer of palisade mesophyll and 6-8 layers of spongy mesophyll which typical stomata were attached on abaxial surface. Dark red inclusions accumulated in epidermal cells were absent (Figure 2.D). Shape of midrib was concave on both surfaces with semicircular shaped vascular bundle without accessory bundle (Figure 2.H). The outline of petiole in transverse section was convex on both adaxial and abaxial surfaces. Surface of petiole lacked trichomes. Prismatic crystals located in parenchyma tissue of cortex and pith. Vascular bundle in petiole was circular shape without accessory bundle. Laticiferous cells were distributing in cortex and pith layers and gelatinous fibers surrounded vascular bundle (Figure 2.B).

\section{Wood anatomical characteristics}

Growth ring boundaries illustrated indistinct (faint). Vessels presented in diffuse porous pattern, radial multiple of 4 cells or more with diagonal and radial arrangements (Figure 3.B) and average diameter of $47.36 \mu \mathrm{m}$. Alternate intervessel pitting (Figure 3.F) and simple perforation plates displayed at the vessel. Axial parenchyma was absent or extremely rare (Figure 3.D). Ray width included 1-3 cell (s) (Figure 3.F) with procumbent, square and upright cells mixed throughout the rays as well as red inclusions (Figure 3.H). The septate fibers observed from transverse section were accompanied by very thin walls (Figure 3.D). 
Table 2. Anatomical characteristics of Chrysophyllum species

\begin{tabular}{|c|c|c|c|c|c|}
\hline \multirow{2}{*}{ Organs } & \multirow{2}{*}{\multicolumn{3}{|c|}{ Anatomical characteristics }} & \multicolumn{2}{|c|}{ Species } \\
\hline & & & & C. cainito & C. roxburghii \\
\hline \multirow[t]{12}{*}{ Leaf surface } & \multirow[t]{6}{*}{ Upper } & \multicolumn{2}{|c|}{ Cutin sculpturing } & $\mathrm{Sm}$ & $\mathrm{Sm}$ \\
\hline & & \multicolumn{2}{|c|}{ Epidermal shape } & Po & $\mathrm{Ji}$ \\
\hline & & \multicolumn{2}{|c|}{ Epidermal wall } & St & St \\
\hline & & \multicolumn{2}{|c|}{ Stoma } & - & - \\
\hline & & \multicolumn{2}{|c|}{ Inclusions in epidermis } & + & - \\
\hline & & \multicolumn{2}{|c|}{ Trichome } & - & - \\
\hline & \multirow[t]{6}{*}{ Lower } & \multicolumn{2}{|c|}{ Cutin sculpturing } & $\mathrm{Sa}$ & $\mathrm{Sa}$ \\
\hline & & \multicolumn{2}{|c|}{ Epidermal shape } & $\mathrm{Ir}$ & $\mathrm{Ji}$ \\
\hline & & \multicolumn{2}{|c|}{ Epidermal wall } & $\mathrm{Cr}, \mathrm{St}$ & $\mathrm{Si}$ \\
\hline & & \multicolumn{2}{|c|}{ Stoma } & $\mathrm{Pa}$ & $\mathrm{An}, \mathrm{Cy}, \mathrm{Pa}$ \\
\hline & & \multicolumn{2}{|c|}{ Inclusions in epidermis } & $\operatorname{Pr}$ & $\operatorname{Pr}$ \\
\hline & & \multicolumn{2}{|c|}{ Trichome } & $\mathrm{Tt}$ & - \\
\hline \multirow{13}{*}{$\begin{array}{l}\text { Lamina } \\
\text { transverse section }\end{array}$} & \multirow[t]{2}{*}{ Leaf margin } & \multirow{2}{*}{\multicolumn{2}{|c|}{$\begin{array}{l}\text { Tip roundness } \\
\text { Curveness }\end{array}$}} & Ac & $\mathrm{Ob}$ \\
\hline & & & & Sl & $\mathrm{Sl}$ \\
\hline & \multirow{8}{*}{ Between leaf margin and midrib } & Trich & & $\mathrm{Tt}$ & - \\
\hline & & Shap & laxial epidermal cell & $\mathrm{Cu}$ & $\mathrm{Ci}, \mathrm{Rc}$ \\
\hline & & Нурс & & - & - \\
\hline & & Leaf & ication & $\mathrm{Bi}$ & $\mathrm{Bi}$ \\
\hline & & Palis & & $1-3$ & 1 \\
\hline & & Spon & & 10 & $6-8$ \\
\hline & & Stom & sition & Ty & Тy \\
\hline & & Inclu & in epidermal cell & $\mathrm{Re}$ & $\mathrm{Re}$ \\
\hline & Midrib & Adax & axial shape & $\mathrm{Cc} / \mathrm{Cv}$ & $\mathrm{Cv} / \mathrm{Cv}$ \\
\hline & & Vasc & andle shape & $\mathrm{He}$ & $\mathrm{Se}$ \\
\hline & & Acce & bundle & 2 & - \\
\hline Petiole & & Outli & petiole & $\mathrm{Cc} / \mathrm{Cv}$ & $\mathrm{Cv} / \mathrm{Cv}$ \\
\hline transverse section & & Trich & & $\mathrm{Tt}$ & - \\
\hline & & Crys & & $\operatorname{Pr}$ & $\operatorname{Pr}$ \\
\hline & & Shap & ascular bundle & $\mathrm{He}$ & $\mathrm{Ci}$ \\
\hline & & Num & vascular bundle & 1 & 1 \\
\hline & & Acce & bundle & - & - \\
\hline & & Gela & fiber in vascular bundle & + & + \\
\hline & & Latic & s cell & + & + \\
\hline Wood & & Grov & & In & In \\
\hline & Vessel & Poro & & $\mathrm{Wd}$ & $\mathrm{Wd}$ \\
\hline & & Grou & & So, $\mathrm{Rm}, \mathrm{Cl}$ & $\mathrm{Rm}$ \\
\hline & & Arra & & $\mathrm{Di}, \mathrm{Ra}$ & $\mathrm{Di}, \mathrm{Ra}$ \\
\hline & & Pittir & & $\mathrm{Al}$ & $\mathrm{Al}$ \\
\hline & & Dian & am) & $63.62 \pm 19.26$ & $47.36 \pm 11.88$ \\
\hline & & Perfo & plate & $\mathrm{Sp}$ & $\mathrm{Sp}$ \\
\hline & Parenchyma & Axia & & $\mathrm{Ag}$ & - \\
\hline & & Ray & Width & $1-3$ & $1-3$ \\
\hline & & & Composition & $\mathrm{Up}, \mathrm{Sq}, \mathrm{Pc}$ & $\mathrm{Up}, \mathrm{Sq}, \mathrm{Pc}$ \\
\hline & & & Inclusions & - & $\mathrm{Re}$ \\
\hline & Fiber & Wall & & $\mathrm{Vk}$ & $\mathrm{Vn}$ \\
\hline & & Sept & & + & + \\
\hline
\end{tabular}

Note:-: Absent, +: Present, Ac: Acute leaf margin, Ag: Diffuse-in-aggregates axial parenchyma, Al: Alternate intervessel pits, An: Anisocytic stomata, Bi: Bifacial leaf, Cc: Concave shape, Ci: Circular shape, Cl: Cluster vessel, Cr: Curve wall, Cu: Cubic shape, Cv: Convex shape, Cy: Cyclocytic stomata, Di: Diagonal arrangement, He: Heart shape, In: Indistinct boundaries, Ir: Irregular shape, Ji: Jigsaw shape, Ob: Obtuse leaf margin, Pa: Paracytic stomata, Pc: Procumbent ray cell, Po: Polygonal shape, Pr: Prismatic crystal, Ra: Radial arrangement, Rc: Rectangular shape, Re: Red inclusions, Rm: Radial multiple of 2-4 vessels, Sa: Striated cutin sculpturing, Se: Semi-circular shape, Si: Sinuous wall, Sl: Slightly downward leaf margin, Sm: Smooth cutin sculpturing, So: Solitary vessel, Sp: Simple perforation plate, Sq: Square ray cell, St: Straight wall, Tt: T-shaped trichome, Ty: Typical stomata, Up: Upright ray cell, Vk: Very thick fiber wall, Vn: Very thin fiber wall and Wd: Wood diffuse-porous vessel 

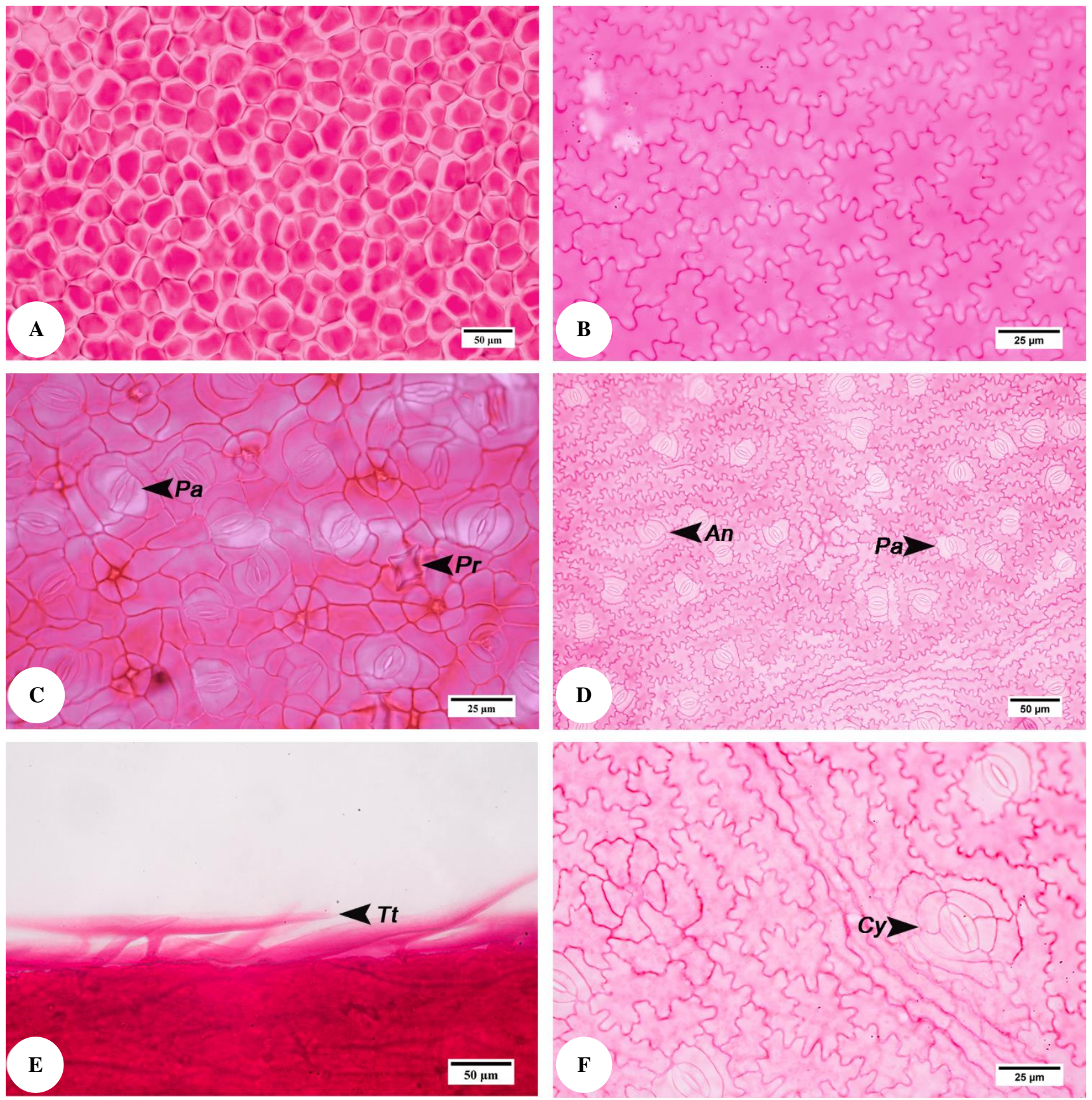

Figure 1. Photomicrographs of leaf peeling and clearings of Chrysophyllum; (A) polygonal shape with straight anticlinal walls on adaxial surface of $C$. cainito, (B) jigsaw shape with sinuous anticlinal wall on adaxial surface of $C$. roxburghii, (C) paracytic stomata on abaxial suface of C. cainito, (D) paracytic and anisocytic stomata on abaxial surface of $C$. roxburghii, (E) T-shaped trichome on abaxial surface of $C$. cainito and $(\mathrm{F})$ cyclocytic stomata on abaxial surface of $C$. roxburghii. Note: An: Anisocytic stomata, Cy: Cyclocytic stomata, Pa: Paracytic stomata, Pr: Prismatic crystal and Tt: T-shaped trichome 


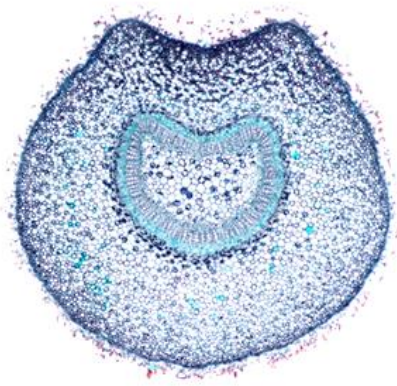

A

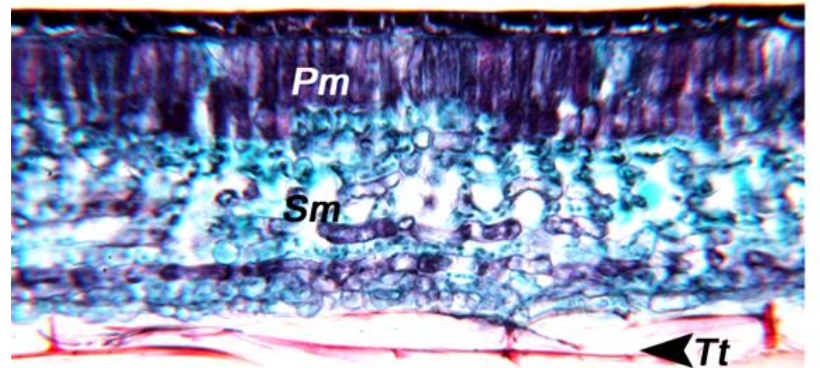

C

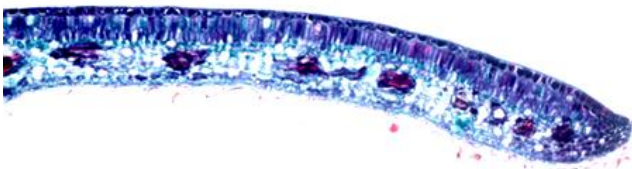

$\mathbf{E}$

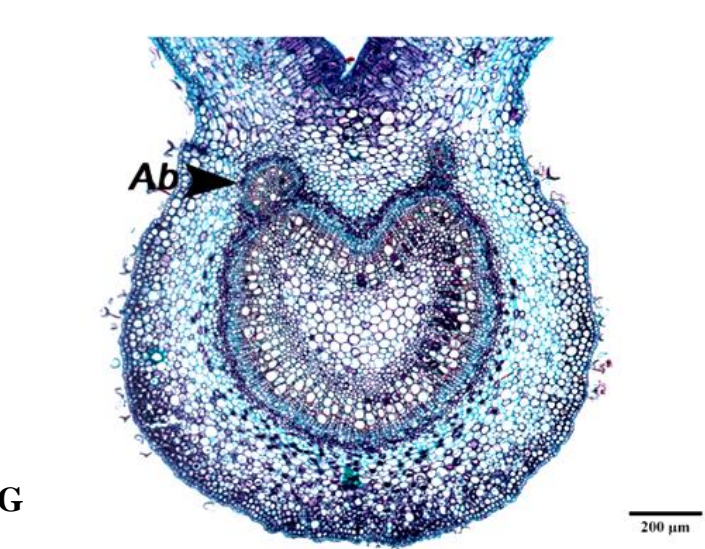

B

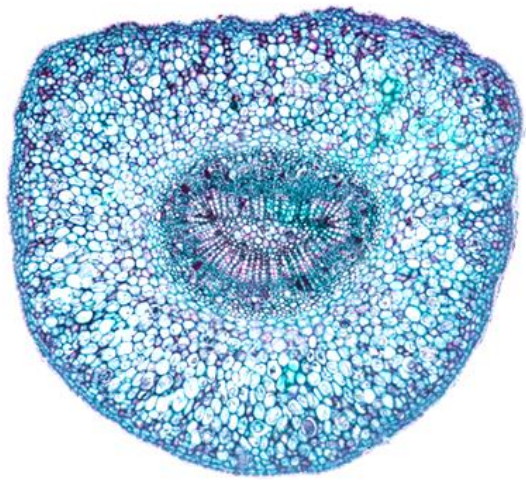

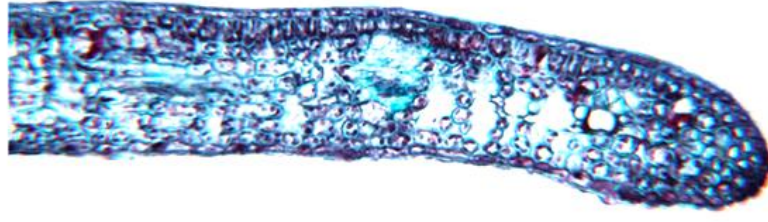

$\mathbf{F}$

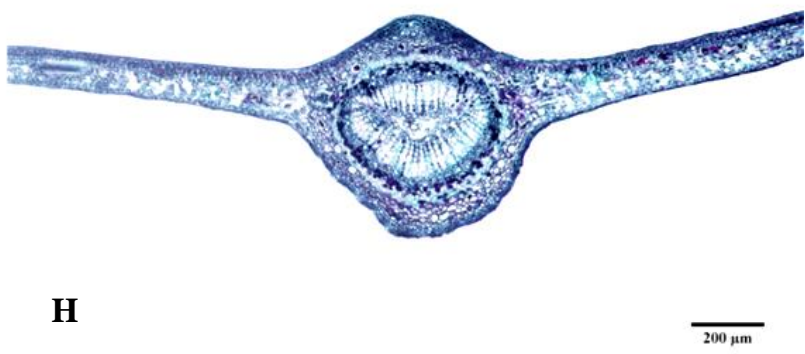

Figure 2. Anatomical characteristics of petiole and lamina in transverse section of Chrysophyllum; (A) heart-shaped vascular bundle in petiole of C. cainito, (B) circular-shaped vascular bundle in petiole of C. roxburghii, (C) T-shaped trichome and mesophyll arrangement of $C$. cainito, (D) prismatic crystal and mesophyll arrangement of C. roxburghii, (E and $\mathrm{F}$ ) leaf margins of C. cainito and C. roxburghii, respectively, $(\mathrm{G})$ vascular bundle in heart shape with two accessory bundles in midrib of $C$. cainito and $(\mathrm{H})$ vascular bundle in semicircular shape without accessory bundle in midrib of $C$. roxburghii. Note: Ab: Accessory bundle, Pm: Palisade mesophyll, Pr: Prismatic crystal, Sm: Spongy mesophyll and Tt: T-shaped trichome 

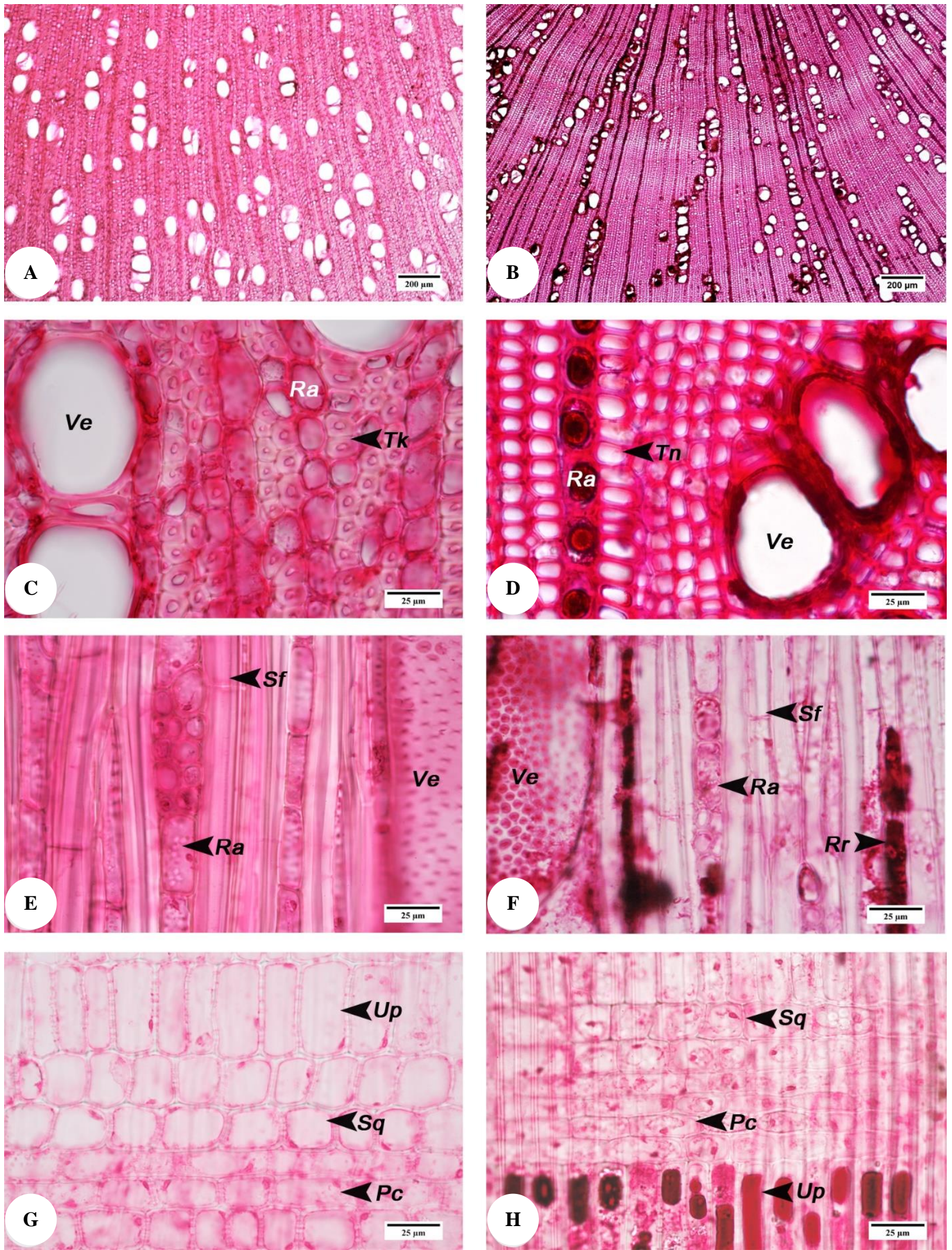

Figure 3. Anatomical characteristics of wood of Chrysophyllum; (A) vessel diffuse porous with partly solitary, radial multiple and small cluster ofC. cainito, (B) vessel diffuse porous with radial multiple of 4 or more and diagonal as well as radial arrangements, (C) rays and very thick walled fiber of $C$. cainito, (D) rays and very thin walled fiber of $C$. roxburghii, (E) septate fiber and rays in tangential section of $C$. cainito, $(\mathrm{F})$ septate fiber and rays in tangential section of $C$. roxburghii, $(\mathrm{G})$ upright, square and procumbent cells in radial section of $C$. cainito, $(\mathrm{H})$ red stained-upright, square and procumbent cells in radial section of $C$. roxburghii. Note: Pc: Procumbent ray cell, Ra: Ray parenchyma, Rr: Red stained inclusions in rays, Sf: Septate fiber, Sq: Square, Tk: Very thick wall fiber, Tn: Very thin wall fiber, Up: Upright ray cell and Ve: Vessel 


\section{Key identification}

Key to species based on lamina surface

1a. Adaxial epidermal cells polygonal-shaped, straight-walled, red inclusions present; T-shaped trichomes present on abaxial surface

C. cainito

1b. Adaxial epidermal cells jigsaw-shaped, sinuous-walled, red inclusions absent; trichomes absent on both surfaces. C. roxburghii

Key to species based on lamina transverse section

1a. Adaxial epidermal cells cubic-shaped, red inclusions present; T-shaped trichomes present on abaxial surface; vascular bundles heart-shaped; accessory bundles present

C. cainito

1b. Adaxial epidermal cells rectangular and circular-shaped, red inclusions absent; trichomes absent on both surfaces; vascular bundle semi-circular-shaped; accessory bundle absent.

C. roxburghii

Key to species based on petiole transverse section

1a. Petiole outlines concave on adaxial surface, convex on abaxial surface; vascular bundles heart-shaped; trichomes present on petiole.

C. cainito

1b. Petiole outlines convex on both surfaces; vascular bundles circular-shaped; trichomes absent on petiole.

C. roxburghii

Key to species based on wood anatomical characteristics

1a. Vessels partly solitary, radial multiple of 2-4 cells, small cluster; axial parenchyma diffuse-in-aggregtes; red inclusions absent in rays; fiber walls very thick................................................................................ C. cainito

1b. Vessels multiple of 4 cells; axial parenchyma extremely rare or absent; red inclusions present in rays; fiber walls very thin.

C. roxburghii

In the present study, the general anatomical characteristics of all Thai Chrysophyllum are as follows: (i) cutin sculpturing smooth on adaxial surfaces and striated on abaxial surface, (ii) paracytic stomata, (iii) prismatic crystal, (iv) leaf margin slightly downward, (v) bifacial leaf, (vi) typical stomata, (vii) vascular bundle in petiole such as number and presence of accessory bundle, gelatinous fiber and inclusions (viii) growth ring, (ix) vessel porosity, arrangement, pitting and perforation plate, (x) ray width and composition and (xi) septate fiber. Those features can be used as an informative tool to separate the genus Chrysophyllum from other genera in the family. On the other hand, there are other characteristics providing ability for diagnosis of the member in this genus mentioned in the detail below.

Metcalfe and Chalk (1957) reported the similar results found in Chrysophyllum including paracytic stomata, trichomes consisting two long arms but the arms sometimes reduced or absent, striated cuticle occurs on the lower side of leaf, epidermal cells on upper side of $C$. cainito are horizontally divided which are suggestive of a transition to the differentiation of hypodermal layer. However, in the current study, hypodermis was not found in both species. The lack of hypodermis in C. cainito is also reported by Inyama et al. (2016), though in their research found hypodermis in other two species of Chrysophyllum. Even though several studies reported that the great majority of species in the family Sapotaceae performs T-shaped or two-armed trichome on leaves (Metcalfe and Chalk 1957; Popovkin et al. 2016; Sossai et al. 2017) and some set this characteristic as one of common features of the family, however, this character do not exist in leaf surfaces of $C$. roxburghii in the present study. For the transverse section of lamina and petiole, the similar characteristics of Chrysophyllum as Metcalfe and Chalk (1957) reported are bifacial leaf with palisade mesophyll attached on the adaxial side, one or more layer (s) of palisade mesophyll, main vascular bundle in form of closed ring and occurrence of solitary crystal. The study of wood anatomy also indicates the same features of Thai Chrysophyllum with previous reports of Kukachka (1978) and Metcalfe and Chalk (1957) reported that Chrysophyllum's porosity essentially diffused, contains multiple of 2-4 vessels and solitary vessels characteristically grouped loosely together to form a radial or oblique pattern and possess simple perforation plate while Solereder (1908) demonstrated that it has scalariform plates with 1-7 bar (s) in $C$. lucumifolium, intervascular pitting alternate, axial parenchyma distributes irregularly, rays 1-3 cells wide, composed of square, upright and procumbent cells, dark gummy and calcium oxalate inclusions (prismatic crystal), septate and gelatinous fibers with thin to very thick walls.

It is noticeable that some anatomical characteristics of Chrysophyllum reported by Solereder (1908), Metcalfe and Chalk (1957), Kukachka (1978), Inyama et al. (2016) and several investigations might have more features than this study, such as the present paper which shows absence of hypodermis layer, main vascular strand axially flatten cylinder on adaxial side in petiole, tylose with large crystal in vessel. On the other hand, it could have less features than the current study, for instance the presence of anisocytic and cyclocytic stomata, inclusions in leaf epidermal cell. These dissimilarities due to the differences 
among species in the genus and some environmental factors effect plant variation.

Nonetheless, all samples investigated are forest trees reaching around 20-30 meters in height, thus leaves which are on the top crown fully exposed to solar radiation. However, in this study, all the results of transverse section of $C$. cainito's leaf blade show it has the anatomy of sun leaves (leaves produced in bright light condition), whereas C. roxburghii perform anatomy of shade leaves (leaves exposed to shade). These anatomical characters are related to the habitat and environment where Chrysophyllum were collected. Even though sun leaves show a greater leaf folia and thicker and higher palisade/spongy mesophyll ratio, shade leaves present the distinctly larger stomatal size, higher amount of chlorophyll per leaf dry mass and area, bigger chloroplast size and higher thylakoid/grana ratio (Beck 2010; Niinemets 2010). Further, Terashima et al. (2001) discussed that the greater mesophyll surface area per unit leaf area in sun leaves promotes carbon dioxide $\left(\mathrm{CO}_{2}\right)$ dissolution into cell wall and thus dwindles resistance to $\mathrm{CO}_{2}$ diffusion from the intercellular spaces to the chloroplast stroma.

In conclusion, the anatomical data of leaf surface, transverse section of lamina and petiole and wood possess valuable informative characteristics for solving the species problems of species identification in the genus Chrysophyllum of family Sapotaceae in Thailand. The data can also be combined with other important attributes such as morphology, molecular biology, phytochemistry and so on for the benefits in plant taxonomy. The present investigation indicates that the anatomical features are significant for species identification including (i) shape and outline of epidermal cell wall, (ii) presence or absence of $\mathrm{T}$-shaped trichome, (iii) presence or absence of inclusions, (iv) shape of vascular bundle and accessory bundle in midrib, (v) shape of petiole and vascular bundle, (vi) grouping type of vessel, (vii) type of axial parenchyma, (viii) presence or absence of inclusions in rays and (ix) thickness of fiber wall. Nevertheless, in order to illustrate the obvious identification based on anatomical criteria of Chrysophyllum in Thailand, maceration technique and both qualitative and quantitative analyses should be taken into consideration for further investigation.

\section{ACKNOWLEDGEMENTS}

We would like to thank the Department of Biology, Faculty of Science, Srinakharinwirot University, Bangkok, Thailand for providing experimental instruments. The first author gratefully acknowledges the financial support of The Institute for the Promotion of Teaching Science and Technology (IPST), Thailand. The authors are very grateful to Forest Herbarium-BKF, Department of National Parks, Wildlife and Plant Conservation, Bangkok for studying of the specimens and thanks to Sukid Rueangruea, Aditep Kongkaw, Nuttapon Benlang and staffs at Khao Chong Nature and Wildlife Education Center, Trang province for giving fieldwork and identified supplies. We are grateful to the SWU plant anatomy group and anonymous reviewers that provided comments to improve this manuscript.

\section{REFERENCES}

Almeida-Jr EB, Araujo JS, Santos-Filho FS, Carmen SZ. 2013. Leaf morphology and anatomy of Manilkara Adans. (Sapotaceae) from northeastern Brazil. Plant Syst Evol 299 (1): 1-9.

Araújo JS, Azevedo AA, Silva LC, Meira RMSA. 2010. Leaf anatomy as an additional taxonomy tool for 16 species of Malpighiaceae found in the Cerrado area (Brazil). Plant Syst Evol 286: 117-131.

Beck CB. 2010. An Introduction to Plant Structure and Development. Cambridge University Press, Cambridge.

Borg D, Richardson JE, Harris DJ, Gauti ER, Hughes M, Inder BM. 2019. Phylogeny of two African genera of Sapotaceae-Englerophytum and Synsepalum. Edinb J Bot 72 (2): 231-267.

Chayamarit K. 2014. Flora of Thailand, Vol. 11 part 4. Office of the Forest Herbarium, Department of National Parks, Wildlife and Plant Conservation, Bangkok.

Das A, Bin NDB, Bhaumik A. 2010. A brief review on Chrysophyllum cainito. IJPI's J Pharmacog Herbal Formul 1 (1): 1-7.

Doan HV, Riyajan S, Iyara R, Chudapongse N. 2018. Antidiabetic activity, glucose uptake stimulation and $\alpha$-glucosidase inhibitory effect of Chrysophyllum cainito L. stem bark extract. BMC Complement Altern Med 18(1): 267.

Faria AD, Pirani JR, Ribeiro JELS, Nylinder S, Terra-Araujo MH, Vieira PP, Swenson U. 2017. Towards a natural classification of Sapotaceae subfamily Chrysophylloideae in the Neotropics. Bot J Linn Soc 185 (1): 27-55.

Gardner S, Sidisunthorn P, Chayamarit K. 2018. Forest Trees of Southern Thailand (Vol. 3). White Lotus, Chonburi.

Gâteblé G, Swenson U. 2019. Pichonia munzingeri (Sapotaceae), a new and rare micro-endemic species from New Caledonia. Candollea 74: $1-7$.

George OA, Adenipikun EO, Fasogbon SA, Oparanozie JA. 2018. Antimicrobial activities of Chrysophyllum albidum leaves, fruits and seeds. Am J Med Sci 10 (1): 28-44.

Hegde H, Arathi A, Mathew A. 2016. Evaluation of antidiabetic activity of hydro alcoholic extract of Chrysophyllum cainito fruits. Int $\mathbf{J}$ Pharm 7: 4422-4428.

Inyama CN, Mbagwu FN, Duru CM. 2015. Morphological relationship among three Chrysophyllum species and their taxonomic implication. Med Aromat Plants 4: 201-204.

Inyama CN, Mbagwu FN, Duru CM. 2016. Taxonomic relationship on some Chrysophyllum species based on anatomical studies. J Med Aromat Plants 5 (2): 1-5.

Koffi N, Ernest AK, Marie-Solange T, Beugre K, Noel ZG. 2009. Effect of aqueous extract of Chrysophyllum cainito leaves on the glycaemia of diabetic rabbits. Afr J Pharm Pharmacol 3 (10): 501-506.

Kukachka BF. 1978. Wood anatomy of the neotropical Sapotaceae VII. Chrysophyllum. Forest Service U.S., Department of Agriculture, Wisconsin.

Li LB, Lin S, Yan J, Wang QL, Fan ZY, Dong QR, Qin JZ and Xie ZG. 2015. Polyphenolic fraction of Chrysophyllum cainito extract induces cell death in osteosarcoma cells. Bangladesh J Pharmacol 10 (4): 972979.

Mallikarjun N, Venugopal TM, Suchitha Y, Swathi D, Prashith KTR, Vinayaka KS. 2011. Antibacterial activity of Chrysophyllum roxburghii G. Don Gen (Sapotaceae) leaves. Res Rev Biomed Biotechnol 2 (1 and 2): 25-27.

Mao LM, Qi XW, Hao JH, Liu HF, Xu QH, and Bu PL. 2015. In vitro, ex vivo and in vivo anti-hypertensive activity of Chrysophyllum cainito L. extract. Int J Clin Exp Med 8 (10): 17912-17921.

Meira NA, Klein LC, Rocha LW, Quintal ZM, Monache FD, Cechinel FV, Quintão NL. 2014. Anti-inflammatory and anti-hypersensitive effects of the crude extract, fractions and triterpenes obtained from Chrysophyllum cainito leaves in mice. J Ethnopharmacol 151 (2): 975-983.

Metcalfe CR, Chalk L. 1957. Anatomy of the Dicotyledons Vol. 2. The Clarendon, Oxford.

Niinemets U. 2010. A review of light interception in plant stands from leaf to canopy in different plant functional types and in species with varying shade tolerance. Ecol Res 25: 693-714. 
Ningsih IY, Zulaikhah S, Hidayat MA, Kuswandi B. 2016. Antioxidant activity of various kenitu (Chrysophyllum cainito L.) leaves extracts from Jember, Indonesia. Agric Agric Sci Procedia 9: 378-385.

Parker IM, Lopez I, Petersen JJ, Anaya N, Cubilla RL, Potter D. 2010 Domestication syndrome in caimito (Chrysophyllum cainito L.): Fruit and seed characteristics. Econ Bot 64 (2): 161-175.

Pennington TD. 1990. Sapotaceae. Flora Neotropica, The New York Botanical Garden, New York.

Pennington TD. 1991. The Genera of Sapotaceae. Royal Botanic Gardens, Kew.

Petersen JJ, Parker IM, Potter D. 2012. Origin and close relatives of a semi-domasticated neotropical fruit tree: Chrysophyllum cainito (Sapotaceae). Am J Bot 99 (3): 585-604.

Pooma R, Suddee S. 2014. Thai Plant Names Tem Smitinand Revised Edition 2014. Office of the Forest Herbarium, Department of National Park, Wildlife and Plant Conservation, Bangkok.

Popovkin AV, Faria AD, Swenson U. 2016. Pouteria synsepala (Sapotaceae: Chrysophylloideae): A new species from the northern littoral of Bahia, Brazil. Phytotaxa 286 (1): 039-046.

Ravichandra NG. 2010. Methods and Techniques in Plant Nematology. PHI Learning, New Delhi.

Santamaria-Aguilar D, Chaves-Fallas JM, Aguilar R. 2016. Two new species of Chrysophyllum (Sapotaceae) endemic to Costa Rica Brittonia 69 (2): 222-230
Shailajan S, Gurjar D. 2014. Pharmacognostic and phytochemical evaluation of Chrysophyllum cainito Linn. leaves. Int J Pharm Sci Rev Res 26 (1): 106-111.

Solereder H. 1908. Systematic Anatomy of The Dicotyledons Vol I. The Clarendon, Oxford.

Sossai BG, Viegas-Aquije G, Santos ARD, Alves-Araujo A. 2017. A new species of Chrysophyllum (Sapotaceae) from the Brazilian Atlantic forest. Phytotaxa 331 (1): 131-136.

Swenson U, Munzinger M. 2016. Five new species and a systematic synopsis of Pycnandra (Sapotaceae), the largest endemic genus in New Caledonia. Aust Syst Bot 29: 1-40.

Swenson U, Nylander JAA, Munzinger J. 2018. Phylogeny, species delimitation and revision of Pleioluma (Sapotaceae) in New Caledonia, a frequently gynodioecious genus. Aust Syst Bot 31 (2): 120.

Swenson U, Nylinder S, Munzinger J. 2013. Towards a natural classification of Sapotaceae subfamily Chrysophylloideae in Oceania and Southeast Asia based on nuclear sequence data. Taxon 62 (4): 746-770.

Terashima I, Miyazawa SI, Hanba YT. 2001. Why are sun leaves thicker than shade leaves? Consideration based on analyses of $\mathrm{CO}_{2}$ diffusion in the leaf. J Pl Res 114: 93-105.

Wheeler EA, Baas P, Gasson PE. 1989. IAWA list of microscopic features for hard wood identification. IAWA Bull 10 (3): 219-33. 